DOI: 10.20472/BMC.2019.009.010

\title{
KÁROLY SZÓKA
}

University of Sopron, Alexandre Lamfalussy Faculty of Economics, Hungary

\section{BRIGITTA KOVÁCS}

University of Sopron, Alexandre Lamfalussy Faculty of Economics, Doctoral School, Hungary

\section{PROCESS ORIENTATION IN THE MODERN CONTROLLING}

\begin{abstract}
:
The controlling is a combination of the target-oriented control activity, the used methods and other soft factors as well. The controlling is constantly changing because it always must meet the current challenges. Each company receives and generates a lot of data, Big Data and Data Mining help in predictive, secure and user-friendly analysis. One of the most important trend is the Industry 4.0 and the compliance to the Digital Business Models through intelligent networks and Cyber-Physical Systems. The controller is responsible for identifying and evaluating the business changes and requirements; so he will support the management in the implementation of it. We are reviewing the importance of the Industry 4.0 and how have to develop the process orientation of controlling at the modern Digital Business Models. In the paper, we will illustrate how can be achieved it by taking into account the Industry 4.0 strategy and how digitalisation can help.
\end{abstract}

\section{Keywords:}

Controlling, Industry 4.0, Process orientation, Digital Business Model

JEL Classification: M49, 011, 020 


\section{Introduction}

In a rapidly changing economic environment, large companies need to respond more quickly to the changing market conditions and the new challenges. Leaders need to make quick and well-grounded decisions that are unthinkable without a well-functioning reporting system. The task of controlling is to provide the management so analysis and advices what used they can make decisions keep the economic aspects in mind maximally (Kovács, 2017).

All this requires adequate information. Of course, companies to make decisions during their operations use information. Any additional and relevant information reduces uncertainty and risk. Attention should be paid to the optimum amount of information, because too much information can cause uncertainty (Koloszár, 2013).

It is well known that competition is nowadays not just about companies or products, but also about processes. The question is who can perform the process more cheaply and efficiently. "In the consumer society, the processes are the way to corporate results and thus to success." (Bodnár-Vida (edit), 2008, p. 7)

\section{$2 \quad$ Process Management and networking}

The business strategy is mediated by process management to operational level. All the time the aim is to satisfy the needs of our customers as efficiently and effectively as possible. A company that can develop standard and efficient processes can gain a significant competitive advantage, this is fact.

The process is a controlled chain of activities for a wanted output. The given process must meet the expected cost, time and quality goals. Process management is process transformation and process control at the same time. If significant changes are required in operation, the first step is to complete and transform the required process. This is a radical intervention that takes into account the new strategic aims. Process control involves measuring process performance, defining process-related goals, and feedback. Transparency of processes is important for both, so we can analyse them carefully (Bodnár, Vida (edit), 2008).

The need for rapid implementation of organizational change and the quick and good market adaptation puts the development of networks at the forefront. Networks are groups of organizations and companies, which businesses are communicating with each other, exchanging ideas, information and resources. One of the essential characteristics of networks is the compound relationship and communication. Another feature is the size of the market. If the market is big (international), then we are not this is the essence of strategic cooperation. This can start with a conference, stronger communication, and then lobbying the companies together, making a research together, sharing resources, etc. The essence is the strategic cooperation. Cost and risk sharing can be outdated, collective knowledge developed, and a network can provide services that are more complex. It can make faster and more intense improvements with real collaborations.

Overall, synergy effects will develop, the market role, strength and revenue of the network will be more attractive. What to do? In the case of networks, the exact goals, responsibilities and authorities must be clarified. The key processes should be described and illustrated, and a description of the processes should be given. Thus, the elements of operation can be optimized. The arrangement and communication system must be both flexible and consistent. 
This concept can be approached from several sides. Control points need to be insert into the processes, where the process is still controllable and we have the opportunity to intervene. There are also differences in the testing process. The difference is not necessarily a mistake, it can be positive difference (something finished before deadline, more product is given) too.

However, it must be known that the deviation will have any consequences. The advantage of the process approach is that it does not seek human errors in the case of problems, but incorrect processes. The goal is to make process control and process development part of the daily operational routine, ie to insert it into the current management system (Szóka, 2009).

It is also a feature of today's controlling, ie that it really works or needs to work in real time. Internal control also plays an important role. A good internal control system directly influences the quality, reliability and competitiveness of the organization (effective and efficient operation, reliability of internal and external financial reporting, compliance with relevant laws, regulations, and internal policies) (Kovács, 2016).

According to Koloszár, the management tools used in the SME sector are insufficient and this has a negative impact on competitiveness. There are efficiency reserves, organizational innovation opportunities that can improve this (process management, lean, value analysis (Koloszár, 2018).

\section{About Industry 4.0}

Industry 4.0 has set new standards in production, smart factories and digitized production are appeared. Its goal is to develop intelligent and networked production that enables more efficient production using Cyber Physical Systems.

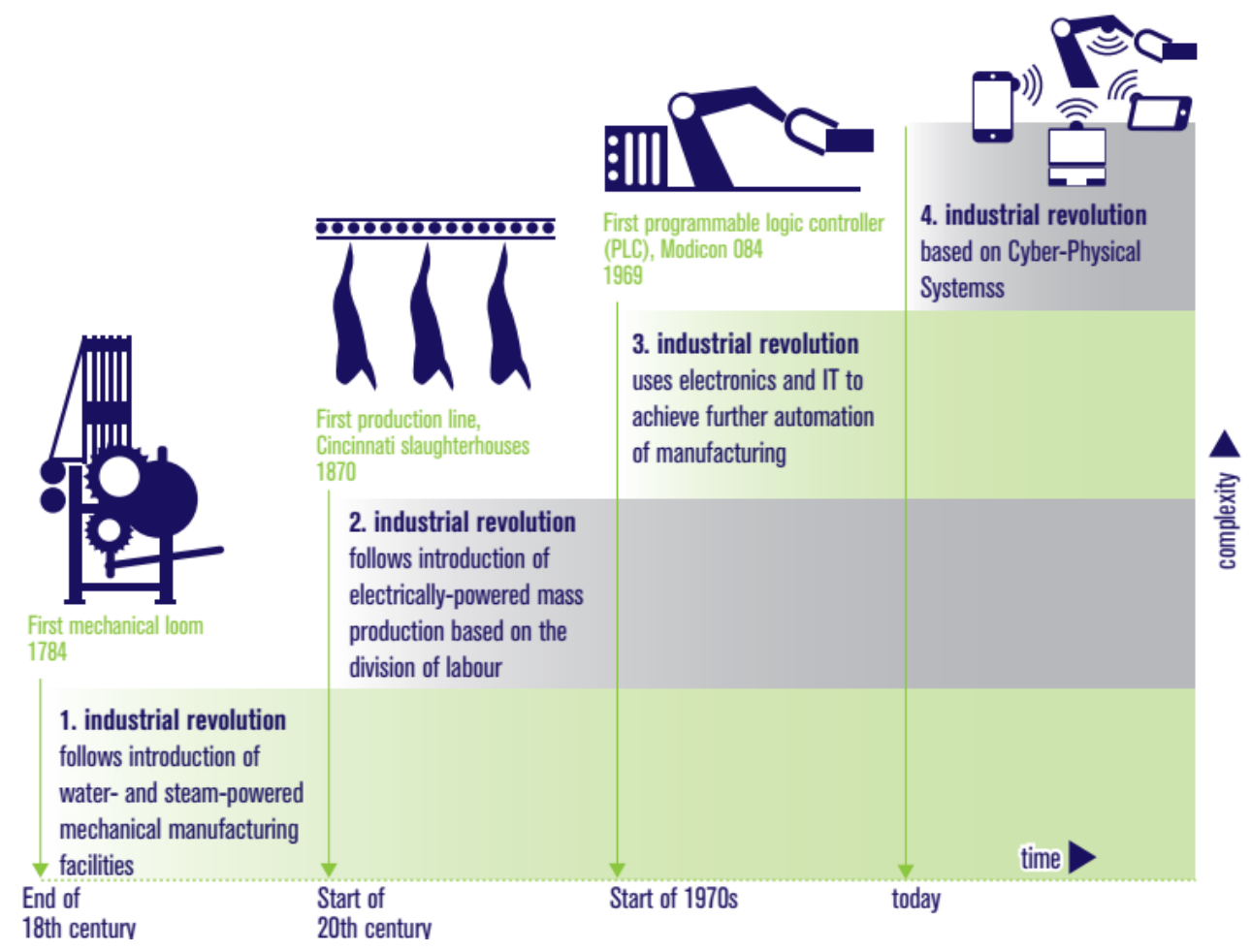

Source: Kagermann, Wahlster, Helbig, 2013.

What does it mean? Physical-real production is links to the digital world, including smart factory, smart product / maintenance / storage, etc. Smart robots are appeared, communication released between software and machines. This is based on the emergence of 
digitalization, Big Data, Artificial Intelligence and digital services during the production processes.

In the value chain, the production and management tools themselves coordinate and organize their operations. With the spread of automation, ratio of human work is falling back in production. In addition, robotization is also spreading in the field of services.

During the Fourth Industrial Revolution, many manpower are released, besides this fewer but more qualified jobs are born. Automation in Europe and the United States threatens the 50$60 \%$ of jobs, while in less developed regions these numbers may be even higher. Obviously, professions that cannot be simplified, require individual thinking and social skills are safe (Varga, Cseh, 2019; World Bank, 2016).

Features of Industry 4.0: horizontal and vertical integration through the value chain, end-toend integration of manufacturing, and networked manufacturing systems. It is important that the process and its control be only realized in real time (Szóka, 2018).

These systems consist of physical, intelligent and networked elements that together form the 'Things of Internet'. Things on the Internet (IOT) can collect, sort, and synchronize data in realtime, using intelligent networks. This is done through so-called Cyber Physical Systems (CPS). It integrates computing and physical processes, uses computers and networks to communicate and control. This CPS structure consists of two main components: 1) advanced level connectivity that ensures real-time data traffic between physical production and cyber space; and 2) intelligent data analysis, which means cyber space. (Lee, 2015.).

\section{$4 \quad$ Digital strategy and robotic report}

What is a digital strategy? "A business strategy, inspired by the capabilities of powerful, readily accessible technologies (like SMACIT), and intent on delivering unique, integrated business capabilities in ways that are responsive to constantly changing market conditions." (Sebastian, Mocker, Ross, Beath, Fonstad, 2017, p. 198)

Today's business model is radically different than it used to be. People take service, not a product, eg. not the car, just the mobility, or I don't want to download the music, just listen. Behind such new types of consumer needs are new types of companies that are networked and contracted. There is a challenge here too; the model of margin or profit calculation is also new, eg. does not sell the machine, but invoices (sell) the machine time.

The management model also changes, immediate and accurate reports are needed, and the focus is on planning forecast deviations instead of plan-fact comparisons. Real-time reporting is required, process automatisation and routine process robotization are needed. Robotic Process Automation (in the following RPA) means the implementation of standardisable processes with software robots. Whether it is a repetitive report or a single analysis, the data must be collected, validated, processed from all the company's departments and transferred to the appropriate report.

The bigger the company, the more heterogeneous the business model and the system, the more complex and costly the process. RPA mimics human behaviour, performs manual activities faster and more efficiently, but needs clear decision rules. It is promising where many manual connection points are and the decision can be made without human intervention. Data should be available (currently expect) and the process is highly standardized. RPA is particularly preferred in the field of planning and production. Here, it is 
necessary to do repetitive tasks according to regulations and thus provide the basis for effective management support (new approach: controller as a business partner).

A typical area is the report compilation: data generation, validation, analysis and reporting, preparation the forecast. Creating and distributing reports using heterogeneous data sources has a great potential for RPA. The use of RPA is not limited to data processing, it can also be used for communication with people and descriptive interpretations (eg. read an e-mail or form, open an attachment, paste data from a attachment into a destination application, verify that a form has been filled in completely, send a reply message, etc.). By using it, you can always achieve a high level of quality and service, thanks to continuous availability and observance to the specified rules. A very important advantage is that by thoroughly examining and standardizing processes in an RPA project, the structures that have developed in the past are usually redesigned and the processes themselves become slimmer. There are few repetitive tasks in strategic planning; many subprocesses work with assumptions, in which case RPA is inappropriate (Isensee, Ostrowicz, Reuschenbach, 2018).

\section{$5 \quad$ Digital business model and modern Process Management}

The process management approach was originally a highly structured, a technical one, often with the aim of automatically implementing the processes. In the past 30 years, process management has developed a lot, see e.g. lean. Digitization brings huge changes.

The focus of the new model is that the manufacturing process and the machines are able to recognize the events and, on that basis, change their operation. (For example, in the case of a decreasing inventory, the machine will order material; or give a signal to the mechanic in case of failure, and prints the necessary fixture with a 3D printer.)

In such a process, many data is generated, the goal is to draw conclusions after the analysis of the data and generate valuable information. Intelligent manufacturing systems and processes are intertwined in these smart factories, so communication is the key to their operation. An important change is decentralization, ie making production flexible and the continuous improvement and development.

However, increasing the efficiency has a 'price', there is a need for clear and highly detailed methods, otherwise the applications and robots cannot perform the processes. Process models need to be technically structured to ensure integration. Measuring success is not a problem, as data are available.

Let us look at the key steps and features. Process Management will be an operational necessity, not an opportunity. Digital processes only work if processes are clearly defined. For this, detailed process models should be developed. It is not possible to discuss a process in the digital world just 'about'. The end-to-end approach is appeared, the fulfilment of customer needs (for example, an order) must be followed throughout the company, automatic fulfilment must be ensured. So we are not thinking about functions anymore (was it a production or logistics task?). Process measurements become standard, as all the necessary data are available. This also means that the result of a step can be measured immediately (eg the effect of reducing lead-time on profit). There is no risk and no change management, because robots and computers do exactly the instructions and do not have to convince them of the correctness of the change (Bergsmann, Brenner 2018). 


\section{Conclusions}

Industry 4.0 represents a high degree of product and process variability. Process modelling, development, and reorganization are areas of today that have grown in importance in the context of Industry 4.0. Digital techniques can effectively support this, but be aware of the conditions and limitations of these techniques.

Many new, powerful, "digitization" techniques have released in recent years, just thinking on social media, mobile data entry and reporting, or Big Data. All of these are important for process management and controlling. In this paper, we reviewed the development opportunities of process management from the point of view of digitization, but the possibilities are still open. It has to be accepted that this process is endless, never ending, we must strive for the best.

A good process management can only be done if we are aware of its elements. They should be discussed at the beginning of the development, that is, when we planning and managing the processes. If a company has restructured its business processes and the new processes are efficient, after a certain period of time it is expected that the business environment and the customer needs will change, and maybe even management too.

\section{References}

BODNÁR, V.; VIDA, G (edit) (2008). Folyamatmenedzsment a gyakorlatban. IFUA Horváth \& Partners, Budapest

BERGSMANN, S.; BRENNER, M. (2018). Prozessmanagement im digitalen Zeitalter. From https://www.horvath-partners.com/de/media-center/artikel/detail/prozessmanagement-imdigitalen-zeitalter/

ISENSEE, J.; OSTROWITZ, S.; REUSCHENBACH, D. (2018). RPA im Controlling, Steigerung der Effizienz im Reporting durch Robotic Process Automation. From https://www.horvathpartners.com/de/media-center/artikel/detail/rpa-im-controlling/

KAGERMANN, H., WAHLSTER, W., HELBIG, J: (2013). Recommendations for implementing the strategic initiative „Industrie 4.0”, Industrie 4.0 Working Group report. Frankfurt/Main. 2013. s. 17. $\begin{array}{lllll}\text { Viewed } & \text { on } & 24 & \text { November } & \text { From }\end{array}$ http://www.acatech.de/fileadmin/user_upload/Baumstruktur_nach_Website/Acatech/root/de/Mate rial_fuer_Sonderseiten/Industrie_4.0/Final_report_Industrie_4.0_accessible.pdf

KOLOSZÁR, L. (2013). Vállalati információs rendszerek. Nyugat-magyarországi Egyetem Kiadó, $\begin{array}{llllll}\text { Sopron, } & 183 & \text { p. } & \text { ISBN } & 978-963-121-6 & \text { From }\end{array}$ http://publicatio.nyme.hu/666/1/ValllnfRendsz_Koloszar_Laszlo.pdf

KOLOSZÁR, L. (2018). Opportunities of lean thinking in improving the competitiveness of the Hungarian SME sector. Management and Production Engineering Review 9(2) pp. 26-41. DOI: $10.24425 / 119523$

KOVÁCS, B. (2017). Új trendek, standardizáció és kihívások a beszámolási rendszerben. (New Trends, Standardization and Challenges in Reporting.) In: Kovács, Tamás; Szóka, Károly (szerk.) XI. Soproni Pénzügyi Napok: „Információs aszimmetria a pénzügyekben, a számvitelben és a tanácsadásban": pénzügyi, adózási és számviteli konferencia: Konferenciakötet. Sopron, Magyarország: Soproni Felsőoktatásért Alapítvány, (2017) pp. 81-86.

KOVÁCS, T. (2016). Belső kontroll funkciók a pénzügyi intézményekben - nemzetközi történeti és fogalmi kitekintés. In: Kulcsár, László; Resperger, Richárd (szerk.) Európa: Gazdaság és Kultúra = Europe: Economy and Culture: Nemzetközi Tudományos Konferencia Sopron, 2016. november 
10. International Scientific Conference: Tanulmánykötet. Sopron, Magyarország: Nyugatmagyarországi Egyetem Kiadó, (2016) pp. 132-137. From http://publicatio.nyme.hu/1235/

LEE, J., ARAKANI, H. D., YANG S., BAGHERI. (2015). Industrial big data analytics and cyber-physical systems for future maintenance \& service innovation. Viewed on 24 November 2017. From http://www.sciencedirect.com/science/article/pii/S2212827115008744

MADAR, N. (2018). A GKI Digital és a Siemens digitalizációs kutatása. From https://assets.new.siemens.com/siemens/assets/public.1536829328.95a166cb-bcff-4119-a5555b738d3ff68c.gkidsiemens_digikutsajto2018hun.pdf

SEBASTIAN, M. S.;. MOCKER, M.; ROSS,J. W.; MOLONEY, K. G.; BEATH, C.; FONSTAD, N. O. (2017). How Big Old CompaniesNavigate Digital Transformation. MIS Quarterly Executive 16:3. From https://core.ac.uk/download/pdf/132606601.pdf

SZÓKA, K. (2009). A kerettervezés problémái - folyamatmenedzsment koncepciója a KKV-nál. In: Svéhlik, Csaba (szerk.) "A tudomány felelössége gazdasági válságban": IV. Kheops Tudományos Konferencia: PhD-hallgatók és kutatók tudományos fóruma: Mór, 2009. május 20. elöadáskötet. Kheops Automobil-Kutató Intézet

SZÓKA, K (2018). The appearance of digitalisation among the viewpoints of Balanced Scorecard. In: Jiri, Rotschedl; Klara, Cermakova (szerk.) Proceedings of the IISES Annual Conference, Prága, Csehország: International Institute of Social and Economic Sciences (IISES), (2018) pp. 284-301. DOI: 10.20472/IAC.2018.035.042

VARGA, J.; CSEH, B. (2019). A negyedik ipari forradalom egyes adózási és munkaerőpiaci hatásai. Pénzügyi tervezés modellezése egy szolgáltató vállalatnál. CONTROLLER INFO 7:1 pp. 11-14., 4 p. (2019) DOI: 10.24387/CI.2019.1.2

WORLDBANK. (2016). Digital Dividends. World Development Report 2016. Washington DC, USA: World Bank. 